Article

\title{
Phosphorus-Sulfur Heterocycles Incorporating an O-P(S)-O or O-P(S)-S-S-P(S)-O Scaffold: One-Pot Synthesis and Crystal Structure Study
}

\author{
Guoxiong Hua, Kate Davidson, David B. Cordes ${ }^{\mathbb{D}}$, Junyi Du, Alexandra M. Z. Slawin and \\ J. Derek Woollins * \\ EaStCHEM School of Chemistry, University of St Andrews, Fife KY16 9ST, UK; gh15@st-andrews.ac.uk (G.H.); \\ kd45@st-andrews.ac.uk (K.D.); dbc21@st-andrews.ac.uk (D.B.C.); jd83@st-andrews.ac.uk (J.D.); \\ amzs@st-andrews.ac.uk (A.M.Z.S.) \\ * Correspondence: jdw3@st-andrews.ac.uk; Tel./Fax: +44-1334-463861
}

Received: 7 September 2017; Accepted: 4 October 2017; Published: 10 October 2017

\begin{abstract}
A new one-pot preparative route was developed to synthesize novel organophosphorus-sulfur heterocycles via the reaction of the four-membered ring thionation reagent [2,4-diferrocenyl-1,3,2,4-diathiadiphosphetane 2,4-disulfide (FCLR, a ferrocene analogue of Lawesson's reagent)] and alkenyl/aryl-diols and $\mathrm{I}_{2}\left(\right.$ or $\left.\mathrm{SOCl}_{2}\right)$ in the presence of triethylamine. Therefore, a series of five- to ten-membered heterocycles bearing an O-P(S)-O or an O-P(S)-S-S-P(S)-O linkage were synthesized. The synthesis features a novel application of the multicomponent reaction, providing an efficient and environmentally benign method for the preparation of the unusual phosphorus-sulfur heterocycles. Seven representative X-ray structures confirm the formation of these heterocycles.
\end{abstract}

Keywords: 2,4-diferrocenyl-1,3,2,4-diathiadiphosphetane 2,4-disulfide; diols; one-pot reaction; iodine oxidation; phosphorus-sulfur heterocycles

\section{Introduction}

Organic disulfides have attracted considerable interest due to their practical applications in biochemistry, pharmacological chemistry, and industrial chemistry as well as their utility as synthetic reagents [1,2]. For instance, disulfides play an important role in the construction of secondary and tertiary polypeptide and protein structures. Furthermore, the formation of unsymmetrical disulfide bonds is required for the synthesis of many biologically active peptides, peptide mimetics [3], prodrugs, and antibiotics [4-6]. Disulfides have also been used for the preparation of self-assembled monolayers (SAMs) [7,8] and monolayer-protected clusters (MPCs) with many versatile properties $[9,10]$. The synthesis and reactivity of compounds containing multi-sulfur linkage have been studied extensively [11-17]. Many methods have been developed to prepare cyclic polysulfides by using either elemental sulfur or other sulfur-transfer reagents, however, these methods often gave poor yields of the desired products and require extreme precaution [18-20]. There are few samples for the synthesis of the sulfur-phosphorus compounds with O-(P)-S-S-(P)-O scaffold. The synthesis of alkyldithiophosphonate salts with O-(P)-S-S-(P)-O scaffold was first reported in 1970 [21]. Lawesson's reagent reacted directly with ethylene glycol, 2,2-dimethyl-1,3-propanediol and 2,2'-dihydroxybiphenyl and tert-butylamine leading to di-tert-butylammonium salts, and the latter were further treated with $\mathrm{I}_{2}$ to give the corresponding cyclic disulfides [22]. Recently, three eight-membered phosphorus-sulfur heterocycles have been prepared via a one-pot reaction of alkenyl-diol with 2,4-diferrocenyl-1,3,2,4-diathiadiphosphetane 2,4-disulfide (FcLR, a ferrocene analogue of Lawesson's reagent) [23]. The development of a highly efficient and systematic method 
for the preparation of phosphorus-sulfur heterocycles incorporating with an -O-P(S)-S-S-P(S)-Oscaffold is still desirable in organic synthesis. Herein, we report the synthesis and characterization of a series of new five- to ten-membered phosphorus-sulfur heterocycles with S-S linkage by treating 2,4-diferrocenyl-1,3,2,4-diathiadiphosphetane 2,4-disulfide (FCLR) with alkenyl-diols or aryl-diols in the presence of triethylamine followed an intramolecular oxidation by $\mathrm{I}_{2}$ or $\mathrm{SOCl}_{2}$, and seven related single crystal x-ray structures.

\section{Results and Discussion}

\subsection{Synthesis and Characterization}

We have reported an efficient route for the synthesis of phosphorus-selenium macrocycles including a series of unusual nine- to fifteen-membered organoselenophosphorus macrocycles by means of Woollins' reagent reacting with disodium alkenyl-diols, followed by in situ ring-closure reaction with appropriate dihalogenoalkanes [24,25]. A highly efficient route has also been developed successfully by our group for synthesis of a series of nevel twelve- to sixteen-membered organophosphorus-sulfur macrocycles via an one-pot three-component condensation of four-membered ring thionation reagent, 2,4-bis(4-methoxyphenyl)-1,3,2,4-dithiadiphosphetane 2,4-disulfide (LR, Lawesson's reagent) or 2,4-diferrocenyl-1,3,2,4-diathiadiphosphetane 2,4-disulfide (FCLR), alkenyl-dithiols or aryl-dithiols and dihaloalkanes in the presence of sodium hydride [26]. We adjusted the methods for the preparation of a series of phosphorus-sulfur heterocycles with the O-P(S)-S-S-P(S)-O scaffold. The preparation and spectroscopic characterization of FcLR have been reported by our group [27]. The one-pot reaction of FCLR with an equimolar amount of alkenyl-diol in the presence of two equimolar amounts of triethylamine at room temperature for $24 \mathrm{~h}$, followed by addition of iodine led to the corresponding eight- to ten-membered phosphorus-sulfur heterocycles 1-6 in good to excellent yields (63\% to $89 \%$ ), respectively, as depicted in Scheme 1. Insoluble (in water or normal organic solvent) side products which we were not able to identify, but which we assume are linear polymers, were found resulting in the incomplete transformation in all cases. The results show that the reactions tolerate diverse alkenyl-diols with the non-branched or the highly-branched chains, however, the non-branched diols were found to be preferable for the formation of the products in high yields in the current heterocyclization in general, for instance, ethylene glycol gave the product 1 in the highest yield (89\%) and the lowest yield (63\%) was found in the formation of product 4 in where the butane-2,3-diol was used as starting material. We speculate that 1-6 was preferentially formed by intramolecular oxidation/cyclization of intermediate $\mathbf{A}$ in the presence of two equivalents of triethylamine.

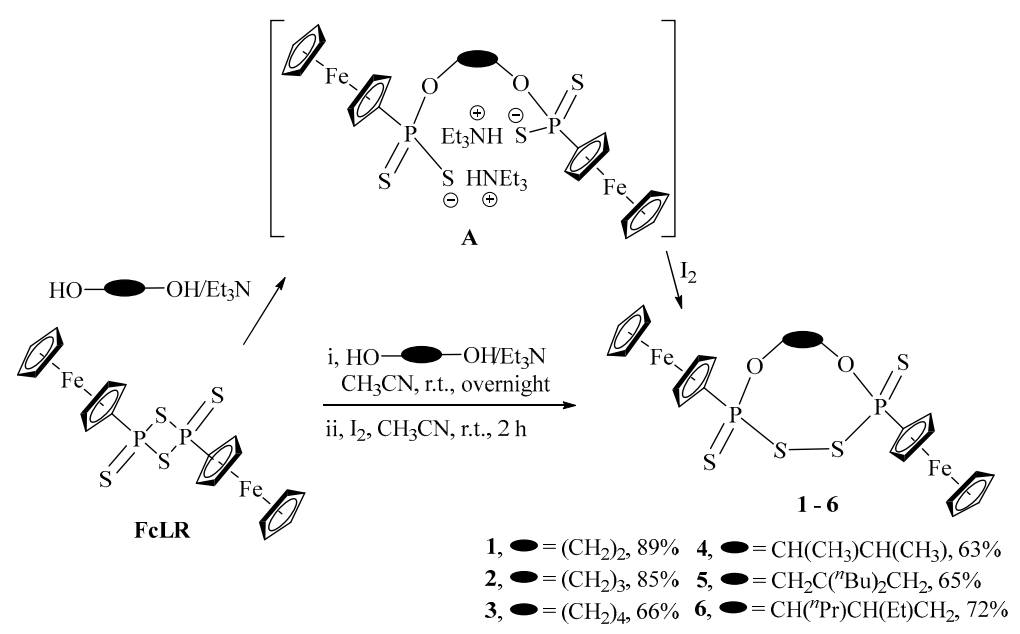

Scheme 1. Synthesis of eight- to ten-membered heterocycles 1-6 from FcLR, alkenyl-diols and $\mathrm{I}_{2}$. 
Similarly, the reaction of 2,4-diferrocenyl-1,3,2,4-diathiadiphosphetane 2,4-disulfide [ $\mathrm{FcP}(\mu-\mathrm{S}) \mathrm{S}]_{2}$ (FCLR) with an equimolar amount of aryl-diol in the presence of two equimolar amounts of triethylamine at room temperature for $24 \mathrm{~h}$, followed by the oxidation using iodine, gave rise to the additional mono-phosphorus species 7, 9 and 11 in $24 \%, 29 \%$ and $41 \%$ yields respectively together with the expected phosphorus-sulfur heterocycles 8, 10 and 12 in moderate yields (36 to $49 \%$ ) as shown in Scheme 2. Once again, in all the cases, insoluble (in water or normal organic solvent) by-products which we were not able to identify were found. The reactions are satisfactory with aryl-diols. The results show that the multiple aromatic ring substitute was preferable to achieve high yields for the formation of both mono-phosphorus species and di-phosphorus heterocycle, for example, when [1,1'-biphenyl]-2,2'-diol is used as diol, the products $\mathbf{1 1}$ and $\mathbf{1 2}$ were obtained in the highest yields, compared to the other cases. We presume that 7, 9 and $\mathbf{1 1}$ were selectively formed by intramolecular cyclization of intermediate $\mathbf{B}$ by loss of a molecule of $\mathrm{FcP}(=\mathrm{S})\left(\mathrm{SHNEt}_{3}\right)$, and $\mathbf{8}, \mathbf{1 0}$ and $\mathbf{1 2}$ were preferentially formed in the same way as compounds 1-6.

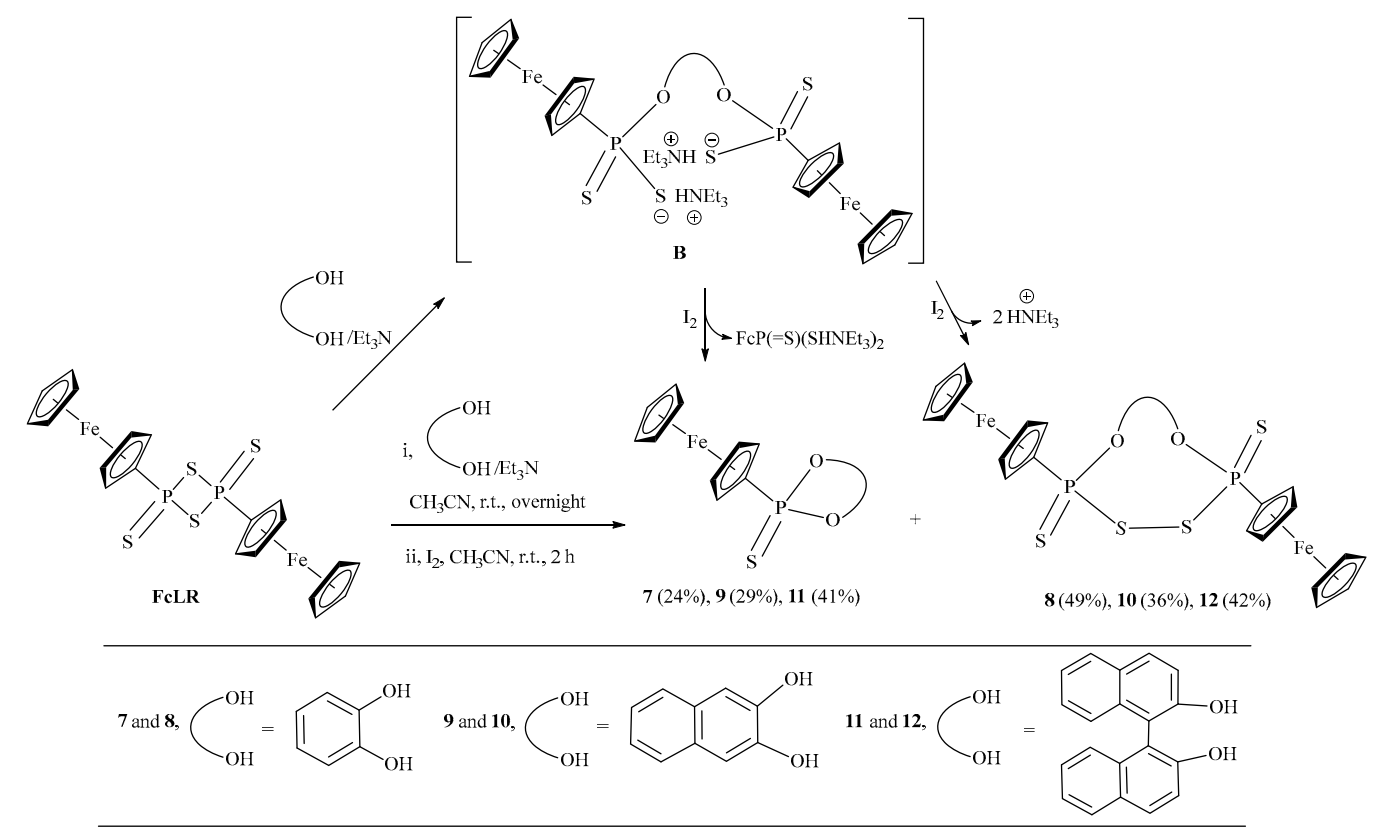

Scheme 2. Synthesis of mono-phosphorus species 7, 9, 11 and di-phosphorus species 8, 10, 12 from FcLR, aryl-diols and $\mathrm{I}_{2}$.

Interestingly, the acyclic product $\mathbf{1 3}$ was obtained in $77 \%$ yield rather than the expected ten-membered heterocycle $\mathbf{D}$ when but-2-yne-1,4-diol was used as the starting material under similar reaction conditions (Scheme 3). The preparation and single crystal structure of the disulfide $\mathbf{1 3}$ has been reported previously [28]; the compound was synthesized by the iodine oxidation of sodium methoxy(ferrocenyl)dithiophosphonate salt, which was obtained from the reaction of Ferrocenyl Lawesson's reagent with sodium metal and methanol. However, in that paper, there are no details of characterization and only two diastereomers were found. Here, four diastereomers (ca. 2:1:1:2 intensity ratio) were found in this product due to the two chiral centers present within the molecule. We propose that the heterocyclic compound D is formed via an oxidation/cyclisation of the intermediate $\mathbf{C}$, however, the heterocycle $\mathbf{D}$ is not stable and readily decomposed to $\mathbf{1 3}$ by the loss of a molecule of $\mathrm{IC} \equiv \mathrm{CI}$ in the presence of the oxidant $\mathrm{I}_{2}$, further investigation of the mechanism is on the way. 


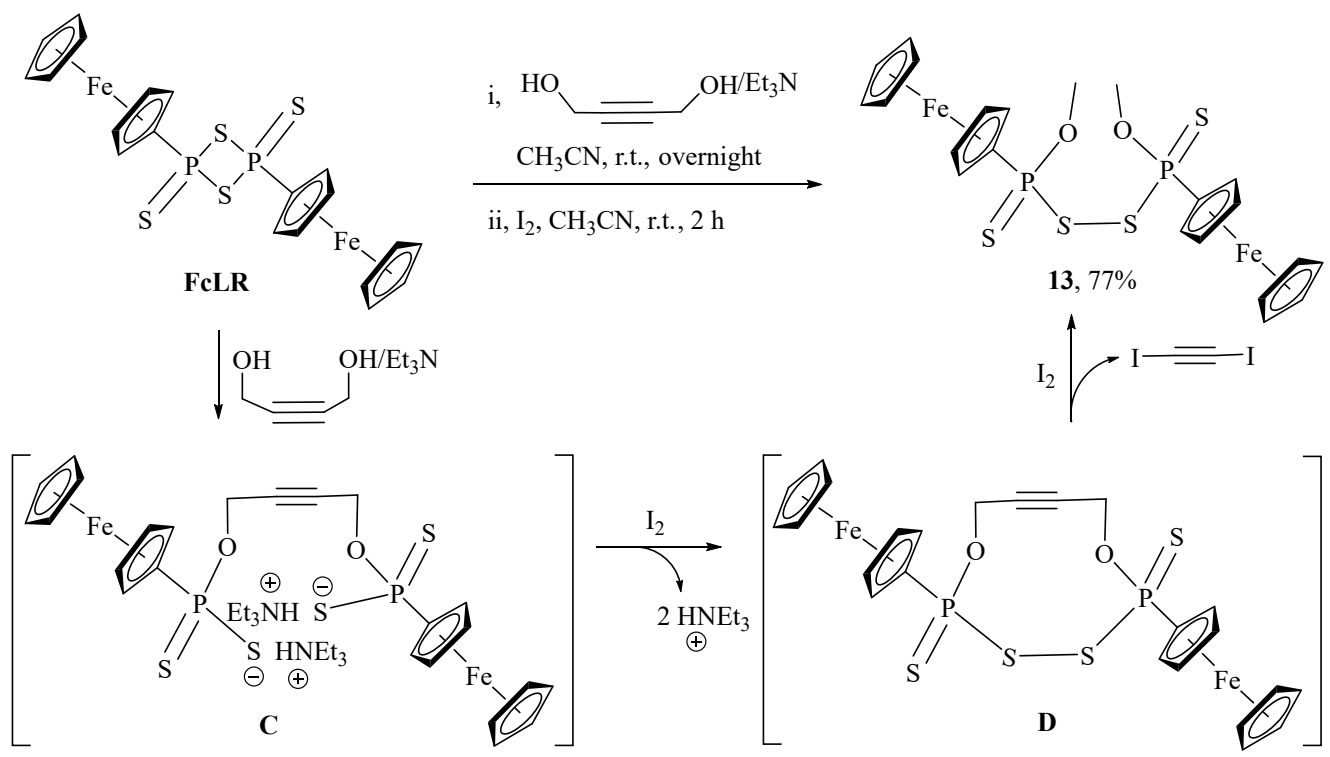

Scheme 3. Synthesis of non-heterocycle 13 from FcLR, but-2-yne-1,4-diol and $\mathrm{I}_{2}$.

Surprisingly, attempts to insert a heteroatom into the heterocyclic ring to create a S-S(O)-S linkage failed, and instead the disulfides 1-3 and $\mathbf{6}$ were obtained from the reaction of FcLR with alkenyl-diols, followed by the addition of $\mathrm{SOCl}_{2}$ at $0{ }^{\circ} \mathrm{C}$ (Scheme 4). Insoluble side products of the reaction were found but we were not able to identify and speculate that they are possibly linear polymers. The average yields of $35 \%, 31 \%, 12 \%$ and $25 \%$ for $1,2,3$ and $\mathbf{6}$, respectively, indicate decreasing yield as the size of the ring increases. The results show that the expected insertion of the sulfoxide building block did not happen, instead a disulfide bond was formed in all cases, indicating the thionyl chloride acted as an oxidant to cause the intramolecular cyclisation rather than acting as a 'building block' to insert into the heterocyclic ring.

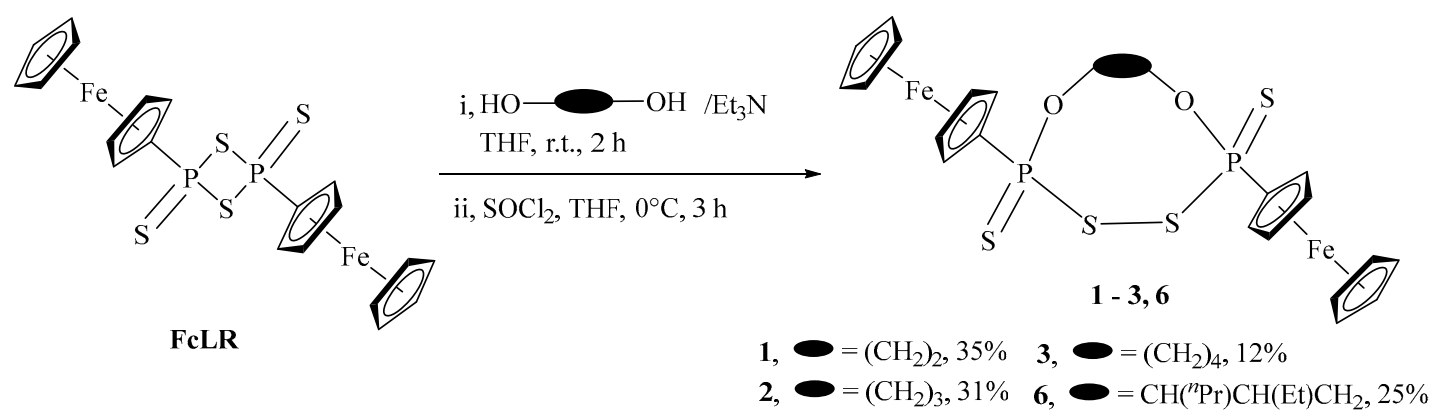

Scheme 4. Synthesis of phosphorus-selenium heterocycles 1-3, 6 from FcLR, alkenyl-diols and $\mathrm{SOCl}_{2}$.

To further investigate the influence of the reaction temperature, the same reaction of FcLR with 2-ethylhexane-1,3-diol and $\mathrm{SOCl}_{2}$ was carried out at $-78^{\circ} \mathrm{C}$. Heterocycle 6 was obtained as the unique product after work-up and the ${ }^{31} \mathrm{P}-\mathrm{NMR}$ spectra of two products are shown in Figure 1. Two apparent differences were found with the intensity ratio of four diastereomers changing from ca. 2:1:1:2 to ca. 1:1:1:1 and the yield increasing from $25 \%$ to $36 \%$. 


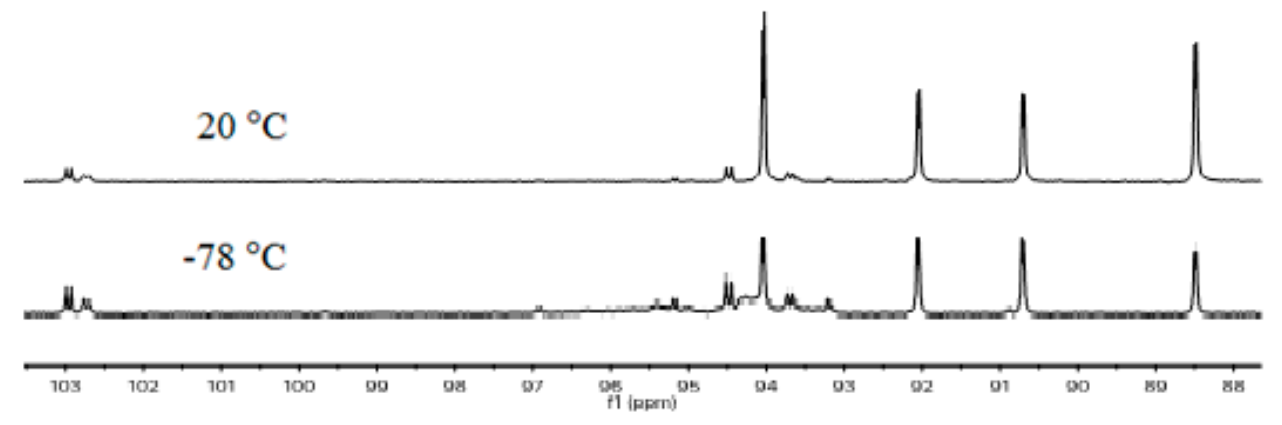

Figure 1. ${ }^{31} \mathrm{P}-\mathrm{NMR}$ spectra of disulfide 6 at the reactions temperatures of $20^{\circ} \mathrm{C}$ and $-78{ }^{\circ} \mathrm{C}$.

The characterization and X-ray structure of compounds 1 [23] and 7 [27] has been reported previously. The characterization of compound 5 has been also reported previously, however, its X-ray structure is not reported yet [22]. The organo-phosphorus-sulfur compounds $\mathbf{2 - 4 , 6 , 8 - 1 2}$ are soluble in common polar organic solvents and are air- and moisture-stable at ambient temperature for several months without any apparent decomposition. Standard analytical and spectroscopic techniques were used for the characterization of all the new compounds. There are two potentially stereogenic centers from two phosphorus atoms in compounds $\mathbf{2}$ and 3 ; four potentially stereogenic centers from two phosphorus atoms and two oxygen atoms attached carbon atoms in compounds 4, 6, 8, 10 and 12. In fact, only one signal is observed in the ${ }^{31} \mathrm{P}-\mathrm{NMR}$ spectra for the compounds $2-4$ and 8, 10 and 12, however, there are four major diastereomers in ca. 2:1:1:2 intensity ratios in $\mathbf{6}$ resulting from four chiral centres which lead potentially to 16 diastereomers within the molecule. Compounds 2-4, 6, 8-12 show the anticipated $[\mathrm{M}]^{+}$or $[\mathrm{M}+\mathrm{H}]^{+}$peak in their mass spectra and satisfactory accurate mass measurements and appropriate isotopic distributions. The ${ }^{1} \mathrm{H}-\mathrm{NMR}$ and ${ }^{13} \mathrm{C}$-NMR spectra of compounds $\mathbf{2 - 4}, \mathbf{6}, \mathbf{8 - 1 2}$ show all the characteristic peaks of the ferrocene backbones. The ${ }^{31}$ P-NMR spectra of di-phosphorus species 2-4, 6, 8, 10 and 12 exhibit sharp singlets in the range of $\delta 88.5$ to $95.6 \mathrm{ppm}$, comparable to the reported values [87.14 to $95.29 \mathrm{ppm}$ ] in the similar analogues [22,23]. Meanwhile, compared to di-phosphorus species 2-4, 6, 8, 10 and 12, the ${ }^{31} \mathrm{P}$-NMR spectrum of mono-phosphorus species $\mathbf{9}$ and $\mathbf{1 1}$ show a sharp singlet with the higher chemical shifts of $\delta 114.1$ and $107.8 \mathrm{ppm}$, respectively, which is similar to the value (113 ppm) in 2 -ferrocenylbenzo[d][1,3,2]-dioxaphosphole 2-sulfide [27]. The results suggest the influence of the introduction of aryl ring into the rings. Detailed NMR spectroscopic analysis of di-phosphorus species $2-4,6,8,10$ and 12 reveals the relatively small coupling constant $\left({ }^{3} J(P, P)=3.8\right.$ to $\left.4.3 \mathrm{~Hz}\right)$ between two four-coordinate phosphorus centres, supporting the presence of the P-S-S-P group and being consistent with the analogous P-S-S-P system in the literature (cf. $\left.{ }^{3} J(\mathrm{P}, \mathrm{P})=4 \mathrm{~Hz}\right)[22,29]$. It should be noted that the chemical shifts of compounds di-phosphorus species 2-4, 6, 8, 10 and 12 are clearly different, indicating substantial differences in heterocyclic conformation.

\subsection{Single Crystal Structure Analysis}

Crystals of phosphorus-sulfur heterocycles 2, 3, 5, 6, 9, 11 and 12 suitable for X-ray crystallographic analysis were grown by diffusion of hexane into a dichloromethane solution of the compound or slow evaporation of a tetrahydrofuran solution of the compound in air at room temperature. The single crystal structures are shown in Figures 2 and 3. The crystallographic data and structure refinement are depicted in Tables 1 and 2. The selected bond lengths and angles are listed in Tables 3 and 4. All structures have a single molecule of the compound in the asymmetric unit except 2, which was found to be co-crystallised with one molecule of chloromethane, and compound 12, which was co-crystallised with half molecule of sulfur $\mathrm{S}_{8}$. The X-ray structures confirm that eight five-to ten-membered rings have formed. 
Table 1. Details of the x-ray data collections and refinements for compounds $2,3,5$ and 6 .

\begin{tabular}{ccccc}
\hline Compound & $\mathbf{2}$ & $\mathbf{3}$ & $\mathbf{5}$ & $\mathbf{6}$ \\
\hline Formula & $\mathrm{C}_{24} \mathrm{H}_{26} \mathrm{Cl}_{2} \mathrm{Fe}_{2} \mathrm{O}_{2} \mathrm{P}_{2} \mathrm{~S}_{4}$ & $\mathrm{C}_{24} \mathrm{H}_{26} \mathrm{Fe}_{2} \mathrm{O}_{2} \mathrm{P}_{2} \mathrm{~S}_{4}$ & $\mathrm{C}_{31} \mathrm{H}_{40} \mathrm{Fe}_{2} \mathrm{O}_{2} \mathrm{P}_{2} \mathrm{~S}_{4}$ & $\mathrm{C}_{28} \mathrm{H}_{34} \mathrm{Fe}_{2} \mathrm{O}_{2} \mathrm{P}_{2} \mathrm{~S}_{4}$ \\
$M$ & 719.26 & 648.35 & 746.45 & 704.46 \\
Crystal system & triclinic & triclinic & monoclinic & triclinic \\
Space group & $P-1$ & $P-1$ & $C 2 / c$ & $P-1$ \\
$a / \AA$ & $7.6366(5)$ & $7.6464(11)$ & $26.246(4)$ & $8.8513(18)$ \\
$b / \AA$ & $11.7048(8)$ & $13.1117(18)$ & $9.6717(15)$ & $13.173(3)$ \\
$c / \AA$ & $16.7834(11)$ & $14.453(2)$ & $13.720(2)$ & $15.034(3)$ \\
$A$ & $98.035(5)$ & $67.778(8)$ & 90 & $106.519(2)$ \\
$B$ & $100.985(6)$ & $83.624(11)$ & $102.900(4)$ & $105.439(3)$ \\
$\Gamma$ & $99.739(17)$ & $73.660(10)$ & 90 & $104.131(3)$ \\
$U / A^{3}$ & $1428.35(17)$ & $1287.2(3)$ & $3394.8(9)$ & $1519.8(6)$ \\
$Z$ & 2 & 2 & 4 & 2 \\
$\mu / \mathrm{cm}$ & 16.286 & 15.968 & 12.214 & 13.591 \\
Reflections collected & 11190 & 16874 & 19978 & 25008 \\
Independent reflections & 4976 & 4632 & 3098 & 5552 \\
$R_{\text {int }}$ & 0.0625 & 0.0405 & 0.0321 & 0.0355 \\
$R 1$ & 0.0455 & 0.0289 & 0.0267 & 0.0244 \\
$w R 2[I>2 \sigma(I)]$ & 0.1145 & 0.0713 & 0.0594 & 0.0575 \\
\hline
\end{tabular}

Table 2. Details of the x-ray data collections and refinements for compounds $\mathbf{9 , 1 1}$ and $\mathbf{1 2}$.

\begin{tabular}{cccc}
\hline Compound & $\mathbf{9}$ & $\mathbf{1 1}$ & $\mathbf{1 2}$ \\
\hline Formula & $\mathrm{C}_{20} \mathrm{H}_{15} \mathrm{FeO}_{2} \mathrm{PS}$ & $\mathrm{C}_{30} \mathrm{H}_{21} \mathrm{FeO}_{2} \mathrm{PS}$ & $\mathrm{C}_{40} \mathrm{H}_{30} \mathrm{Fe}_{2} \mathrm{O}_{2} \mathrm{P}_{2} \mathrm{~S}_{8}$ \\
$M$ & 406.22 & 532.38 & 972.80 \\
Crystal system & triclinic & monoclinic & Triclinic \\
Space group & $P-1$ & $P 2{ }_{1} / n$ & $P-1$ \\
$a / \AA$ & $7.4940(13)$ & $7.8541(16)$ & $10.874(4)$ \\
$b / \AA$ & $10.6802(16)$ & $10.884(2)$ & $14.866(3)$ \\
$c / \AA$ & $10.8335(18)$ & $27.176(5)$ & $15.261(4)$ \\
$\alpha$ & $90.128(5)$ & 90 & $62.01(2)$ \\
$\beta$ & $94.864(5)$ & $92.738(6)$ & $79.51(3)$ \\
$\gamma$ & $101.765(5)$ & 90 & $77.78(3)$ \\
$U / A^{3}$ & $845.6(2)$ & $2320.5(8)$ & $2119.3(11)$ \\
$Z$ & 2 & 4 & 2 \\
$\mu /$ cm & 11.192 & 8.362 & 11.882 \\
Reflections collected & 13750 & 27298 & 25606 \\
Independent reflections & 3066 & 4241 & 7692 \\
$R_{\text {int }}$ & 0.0319 & 0.1309 & 0.1469 \\
$R 1$ & 0.0253 & 0.0586 & 0.1261 \\
$w R 2[I>2 \sigma(I)]$ & 0.1244 & 0.1236 & 0.3345 \\
\hline
\end{tabular}

The single crystal structures of 2, 3, 5, 6 and 12 (Figure 2) adopt highly puckered nine- or ten-membered rings with the two ferrocenyl rings pointing towards the top and bottom of the heterocyclic cavity; meanwhile the two exo-cyclic sulfur atoms are trans to each other. In addition, all endo-cyclic heteroatoms $(\mathrm{O}, \mathrm{P}, \mathrm{S})$ are in zigzag position. The angles between the mean plane of two phosphorus atoms and two oxygen atoms $\left(\mathrm{P}_{2} \mathrm{O}_{2}\right)$, and two adjacent $C p$ rings are $86.93^{\circ}$ and $89.95^{\circ}$ in $2,87.31^{\circ}$ and $89.72^{\circ}$ in $3,88.35^{\circ}$ and $88.35^{\circ}$ in $5,89.02^{\circ}$ and $89.08^{\circ}$ in 6 , and $79.00^{\circ}$ and $89.89^{\circ}$ in 12 . The angles between the mean plane of two phosphorus atoms and two oxygen atoms $\left(\mathrm{P}_{2} \mathrm{O}_{2}\right)$, and two endo-cyclic naphthalene rings are $78.18^{\circ}$ and $79.89^{\circ}$, meanwhile the two endo-cyclic naphthalene rings are inclined to almost vertical $\left[85.49^{\circ}\right]$ in 12 . In the solid state, the structure of 5 adopts a more symmetrical conformation than 2, 3, 6 and 12. The transannular P...P distances are 4.521, 4.604, 4.473, 4.510 and $4.673 \AA$ in $\mathbf{2 , 3}, \mathbf{5}, \mathbf{6}$ and $\mathbf{1 2}$, respectively, falling in the ranges that have been reported in the related P-S containing heterocycles [4.97-6.97] [30]. The geometry around $\mathrm{P}(1)$ and $\mathrm{P}(2)$ is distorted tetrahedral $\left[\mathrm{S}(1)-\mathrm{P}(1)-\mathrm{S}(3) \text { and } \mathrm{S}(2)-\mathrm{P}(2)-\mathrm{S}(4): 103.88(8)^{\circ} \text { and } 105.07(7)^{\circ} \text { in } 2,104.81(5)^{\circ} \text { and } 103.75(4)\right]^{\circ}$ in $3,105.39(3)^{\circ}$ and $105.39(3)^{\circ}$ in $5,102.35(3)^{\circ}$ and $104.07(4)^{\circ}$ in 6 , and $103.9(2)^{\circ}$ and $105.70(19)^{\circ}$ in 12, being smaller than those observed in the P-S containing macrocycles [25] and in related P-Se containing macrocycles [24]. The P-S single bond distances are in the range of 2.093(6) to 2.1087(10) $\AA$ and $P=S$ double bond lengths in the range of 1.916(5) to 1.9324(16) $\AA$ in the structures of 2, 3, 5, 6 and 12 are 
marginally shorter than the values [1.934(4) to 1.950(7) $\AA$ ] for the $\mathrm{P}=\mathrm{S}$ moiety in phosphorus-sulfur macrocycles [31].
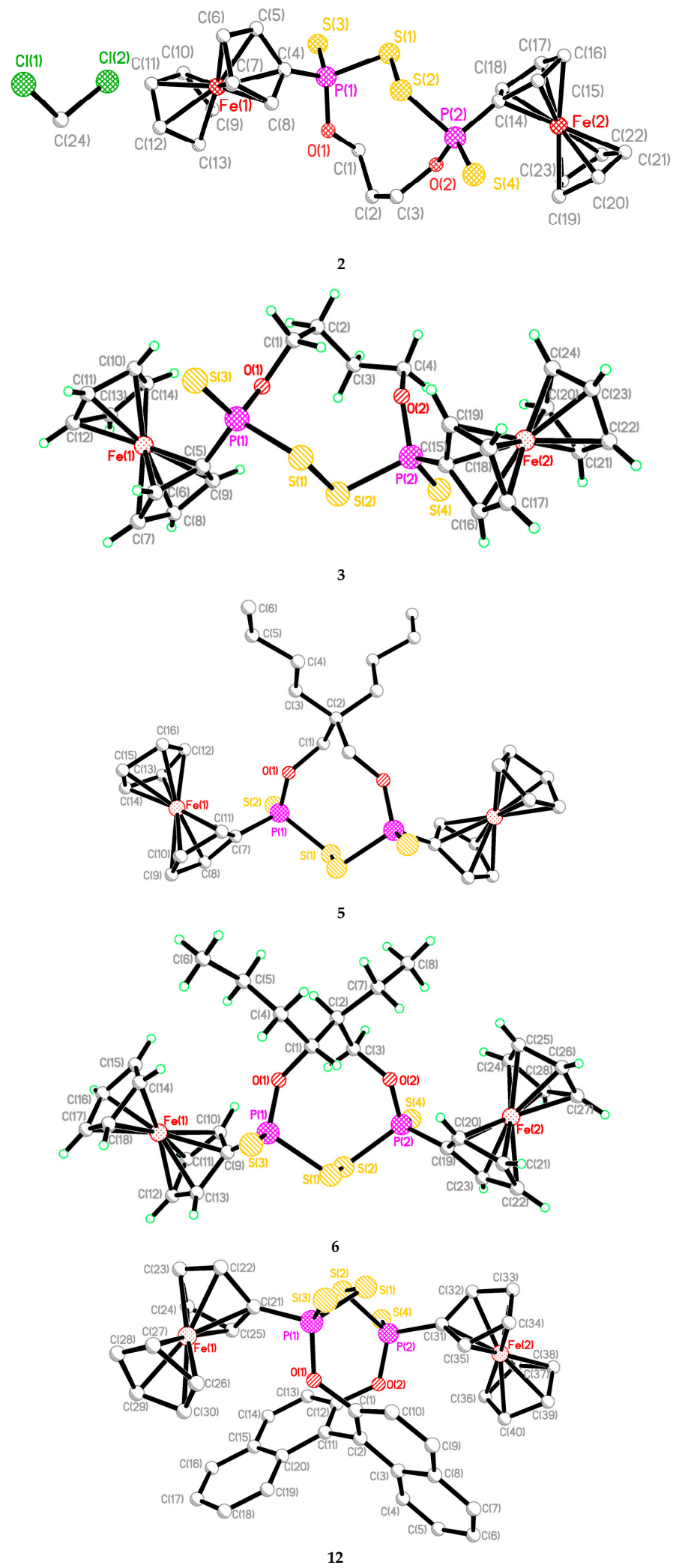

Figure 2. Single crystal X-ray structures of 2, 3, 5, 6 and 12. 
Table 3. Selected bond lengths $(\AA)$ and angles $\left(^{\circ}\right)$ (esds in parentheses) for the structures of 2, 3, 5, 6 and 12.

\begin{tabular}{cccccc}
\hline & $\mathbf{2}$ & $\mathbf{3}$ & $\mathbf{5}$ & $\mathbf{6}$ & $\mathbf{1 2}$ \\
\hline $\mathrm{S}(1)-\mathrm{P}(1)$ & $2.099(2)$ & $2.1026(9)$ & $2.1034(8)$ & $2.1076(8)$ & $2.093(6)$ \\
$\mathrm{S}(2)-\mathrm{P}(2)$ & $2.104(2)$ & $2.1087(10)$ & $2.1034(8)$ & $2.1031(8)$ & $2.107(5)$ \\
$\mathrm{S}(3)-\mathrm{P}(1)$ & $1.930(2)$ & $1.9324(16)$ & $1.9210(9)$ & $1.9271(7)$ & $1.916(5)$ \\
$\mathrm{S}(4)-\mathrm{P}(2)$ & $1.928(2)$ & $1.9255(12)$ & $1.9210(9)$ & $1.9286(7)$ & $1.921(5)$ \\
$\mathrm{O}(1)-\mathrm{P}(1)$ & $1.584(3)$ & $1.587(2)$ & $1.5784(14)$ & $1.5846(14)$ & $1.613(7)$ \\
$\mathrm{O}(2)-\mathrm{P}(2)$ & $1.581(3)$ & $1.5830(19)$ & $1.5784(14)$ & $1.5828(16)$ & $1.603(8)$ \\
$\mathrm{S}(1)-\mathrm{S}(2)$ & $2.072(2)$ & $2.0789(11)$ & $2.0723(9)$ & $2.0739(7)$ & $2.064(4)$ \\
\hline $\mathrm{S}(1)-\mathrm{P}(1)-\mathrm{S}(3)$ & $103.88(8)$ & $104.81(5)$ & $105.39(3)$ & $102.35(3)$ & $103.9(2)$ \\
$\mathrm{S}(2)-\mathrm{P}(2)-\mathrm{S}(4)$ & $105.07(7)$ & $103.75(4)$ & $105.39(3)$ & $104.07(4)$ & $105.70(19)$ \\
$\mathrm{S}(1)-\mathrm{P}(1)-\mathrm{O}(1)$ & $107.63(13)$ & $107.44(7)$ & $106.92(6)$ & $108.93(6)$ & $107.3(4)$ \\
$\mathrm{S}(2)-\mathrm{P}(2)-\mathrm{O}(2)$ & $107.80(13)$ & $108.12(7)$ & $106.92(6)$ & $106.20(6)$ & $107.2(4)$ \\
$\mathrm{S}(3)-\mathrm{P}(1)-\mathrm{O}(1)$ & $118.95(14)$ & $118.77(6)$ & $119.24(8)$ & $119.55(6)$ & $118.7(3)$ \\
$\mathrm{S}(4)-\mathrm{P}(2)-\mathrm{O}(2)$ & $117.84(15)$ & $118.77(6)$ & $118.91(10)$ & $119.13(5)$ & $117.7(3)$ \\
$\mathrm{P}(1)-\mathrm{S}(1)-\mathrm{S}(2)$ & $103.96(8)$ & $102.06(4)$ & $103.72(3)$ & $105.11(3)$ & $106.9(2)$ \\
$\mathrm{P}(2)-\mathrm{S}(2)-\mathrm{S}(1)$ & $102.63(7)$ & $104.42(4)$ & $103.72(3)$ & $102.76(3)$ & $105.18(17)$ \\
\hline
\end{tabular}

The single crystal structures of $\mathbf{9}$ and $\mathbf{1 1}$ confirm that the five- or seven-membered rings have formed (Figure 3). In the solid state, the structures of $\mathbf{9}$ and $\mathbf{1 1}$ have dihedral angles of $8.54^{\circ}$ and $56.13^{\circ} / 60.99^{\circ}$ between the mean plane of phosphorus atom and two oxygen atoms (O-P-O) and aryl ring. The angles between the mean plane of phosphorus atom and two oxygen atoms (O-P-O), and the adjacent $C p$ ring are $88.81^{\circ}$ and $72.67^{\circ}$ in 9 and 11. The geometry around $P$ is distorted tetrahedral $\left[\mathrm{S}(1)-\mathrm{P}(1)-\mathrm{O}(1)\right.$ and $\mathrm{S}(1)-\mathrm{P}(1)-\mathrm{O}(2): 116.10(7)^{\circ}$ and $115.32(7)^{\circ}$ in 9 , and $109.46(13)^{\circ}$ and $118.65(13)^{\circ}$ in 11], being considerably shorter than that $\left(117.0(2)^{\circ}\right.$ in 2-ferrocenylbenzo $[d][1,3,2]$ dioxaphosphole 2-sulfide [27], but being much larger than those observed in 2, 3, 5, 6 and 12 and the P-S containing macrocycles [25]. The $\mathrm{P}=\mathrm{S}$ double bonds in the range of 1.8971(10) $\AA$ to 1.9103(17) $\AA$ are similar to that (1.893(2) $\AA$ ) in 2-ferrocenylbenzo[ $d][1,3,2]$ dioxaphosphole 2-sulfide [27] and marginally shorter than that (1.916(5) to 1,9324(16) $\AA$ ) in 2, 3, 5, $\mathbf{6}$ and 12 and significantly shorter than values (1.934(4) to $1.950(7) \AA$ ) for the $\mathrm{P}=\mathrm{S}$ moiety in phosphorus-sulfur macrocycles [31].
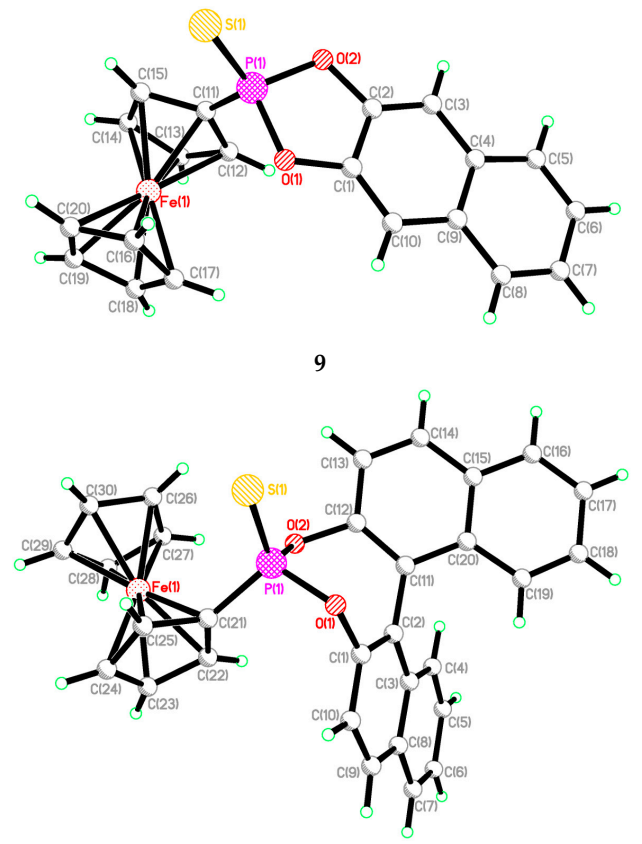

11

Figure 3. Single crystal X-ray structures of $\mathbf{9}$ and $\mathbf{1 1}$ (hydrogen atoms omitted for clarity). 
Table 4. Selected bond lengths $(\AA)$ and angles $\left(^{\circ}\right)$ (esds in parentheses) for the structures of 9 and 11.

\begin{tabular}{ccc}
\hline & $\mathbf{9}$ & $\mathbf{1 1}$ \\
\hline $\mathrm{S}(1)-\mathrm{P}(1)$ & $1.9034(8)$ & $1.9103(17)$ \\
$\mathrm{O}(1)-\mathrm{P}(1)$ & $1.6303(8)$ & $1.606(3)$ \\
$\mathrm{O}(2)-\mathrm{P}(1)$ & $1.6328(17)$ & $1.608(3)$ \\
$\mathrm{O}(1)-\mathrm{C}(1)$ & $1.390(3)$ & $1.409(5)$ \\
$\mathrm{O}(2)-\mathrm{C}(2)$ & $1.390(3)$ & $1.393(5)$ \\
\hline $\mathrm{S}(1)-\mathrm{P}(1)-\mathrm{O}(1)$ & $116.10(7)$ & $109.46(13)$ \\
$\mathrm{S}(1)-\mathrm{P}(1)-\mathrm{O}(2)$ & $115.32(7)$ & $118.65(13)$ \\
$\mathrm{O}(1)-\mathrm{P}(1)-\mathrm{O}(2)$ & $95.56(9)$ & $102.17(16)$ \\
$\mathrm{P}(1)-\mathrm{O}(1)-\mathrm{C}(1)$ & $110.60(15)$ & $118.4(3)$ \\
$\mathrm{P}(1)-\mathrm{O}(2)-\mathrm{C}(2)$ & $110.61(15)$ & $120.3(3)$ \\
\hline
\end{tabular}

\section{Materials and Methods}

\subsection{General Information}

Unless otherwise stated, all reactions were carried out under on oxygen free nitrogen atmosphere using pre-dried solvents and standard Schlenk techniques, subsequent chromatographic and work up procedures were performed in air. ${ }^{1} \mathrm{H}(400.1 \mathrm{MHz}),{ }^{13} \mathrm{C}(100.6 \mathrm{MHz}),{ }^{31} \mathrm{P}-\left\{{ }^{1} \mathrm{H}\right\}(162.0 \mathrm{MHz})$ and ${ }^{77} \mathrm{Se}-\left\{{ }^{1} \mathrm{H}\right\}$ (51.4 MHz referenced to external $\left.\mathrm{Me}_{2} \mathrm{Se}\right) \mathrm{NMR}$ spectra were recorded at $25{ }^{\circ} \mathrm{C}$ (unless stated otherwise) on Advance II 400s (Bruker, Blue Lion Biotech, Carnation, WA, USA) and GSX 270 (JEOL, Inc., Peabody, MA, USA) spectrometers. IR spectra were recorded as KBr pellets in the range of $4000-250 \mathrm{~cm}^{-1}$ on a 2000 FTIR/Raman spectrometer (Perkin-Elmer, Beaconfield, UK). Mass spectrometry was performed by the EPSRC National Mass Spectrometry Service Centre, Swansea. X-ray diffraction data for compound 2 were collected at $125 \mathrm{~K}$ using the St Andrews Automated Robotic Diffractometer (STANDARD) [32], consisting of a sealed-tube generator (Rigaku, Houston, TX, USA) equipped with a SHINE monochromator [Mo K $\alpha$ radiation $(\lambda=0.71075 \AA)$ ], and a Saturn 724 CCD area detector, coupled with a Microglide goniometer head and an ACTOR SM robotic sample changer. Diffraction data for compounds 3, 5, 6, 9, 11 and 12 were collected at either $93 \mathrm{~K}$ (3) or 173 K (all other crystals) by using a Rigaku FR-X Ultrahigh Brilliance Microfocus RA generator/confocal optics and Rigaku XtaLAB P200 system, with Mo K $\alpha$ radiation $(\lambda=0.71075 \AA)$. Intensity data were collected using $\omega$ steps accumulating area detector images spanning at least a hemisphere of reciprocal space. All data were corrected for Lorentz polarization effects. A multi-scan absorption correction was applied by using CrystalClear $[33,34]$. Structures were solved by either charge-flipping (SUPERFLIP) [35] or direct (SIR2004, SIR2011) [36,37] methods, and refined by full-matrix least-squares against $\mathrm{F}^{2}$ (SHELXL-2013) [38]. Non-hydrogen atoms were refined anisotropically, and hydrogen atoms were refined using a riding model. All calculations were performed using the CrystalStructure interface [39]. These data can be obtained free of charge via www.ccdc.cam.ac.uk/conts/retrieving.html or from the Cambridge Crystallographic Data centre, 12 Union Road, Cambridge CB2 1EZ, UK; fax (+44) 1223-336-033; e-mail: deposit@ccdc.cam.ac.uk. CCDC Nos. 1572696-1572702.

\subsection{Synthesis}

3.2.1. General Procedure for the Reaction of FcLR with Alkenyl-diols and $I_{2}$ in the Presence of Triethylamine

A mixture of alkenyl-diol $(1.0 \mathrm{mmol})$ and FcLR $(0.56 \mathrm{~g}, 1.0 \mathrm{mmol})$ in dry acetonitrile $(40 \mathrm{~mL})$ was stirring in the presence of triethylamine $(0.202 \mathrm{~g}, 2.0 \mathrm{mmol})$ at room temperature overnight. $\mathrm{I}_{2}$ solution $(0.254 \mathrm{~g}, 1.0 \mathrm{mmol})$ in acetonitrile $(15 \mathrm{~mL})$ was added dropwise during $2 \mathrm{~h}$ and the mixture was continued stirring for another $2 \mathrm{~h}$. Upon removing solvent, the residue was extracted with dichloromethane $(20 \mathrm{~mL} \times 3)$. After removal of the solvent, the crude product was purified by silica column (dichloromethane as eluent) to give the di-phosphorus species 1-6. 
2,5-Diferrocenyl-1,6,3,4,2,5-dioxadithiadiphosphonane 2,5-disulfide (2). Pale yellow solid (0.54 g, 85\%). M.p. 189-190 ${ }^{\circ} \mathrm{C}$. Selected IR (KBr, cm $\left.{ }^{-1}\right)$ : 1459(m), 1408(m), 1265(m), 1184(s), 1104(m), 1076(m), 1029(s), 990(s), 972(s), 841(s), 815(s), 751(s), 732(s), 663(s), 543(s), 492(s), $459(\mathrm{~m}) .{ }^{1} \mathrm{H}-\mathrm{NMR}\left(400.1 \mathrm{MHz}, \mathrm{CDCl}_{3}, \delta\right)$, $4.83-4.52(\mathrm{~m}, 8 \mathrm{H}), 4.37(\mathrm{~s}, 10 \mathrm{H}), 4.18(\mathrm{dt}, J(\mathrm{P}, \mathrm{H})=10.5 \mathrm{~Hz}, J(\mathrm{H}, \mathrm{H})=5.9 \mathrm{~Hz}, 4 \mathrm{H}), 2.26-2.21(\mathrm{~m}, 2 \mathrm{H})$ ppm. ${ }^{13} \mathrm{C}-\mathrm{NMR}\left(100.6 \mathrm{MHz}, \mathrm{CDCl}_{3}, \delta\right), 74.9(\mathrm{~d}, J(\mathrm{P}, \mathrm{C})=144.5 \mathrm{~Hz}), 72.6(\mathrm{~d}, J(\mathrm{P}, \mathrm{C})=11.6 \mathrm{~Hz})$, $71.9(\mathrm{~d}, J(\mathrm{P}, \mathrm{C})=12.9 \mathrm{~Hz}), 70.5,60.5,28.6 \mathrm{ppm} .{ }^{31} \mathrm{P}-\mathrm{NMR}\left(162.0 \mathrm{MHz}, \mathrm{CDCl}_{3}, \delta\right), 92.9 \mathrm{ppm}$. Accurate mass measurement $\left[\mathrm{EI}^{+}, m / z\right]: 633.8833[\mathrm{M}]^{+}$, calculated mass for $\mathrm{C}_{23} \mathrm{H}_{24} \mathrm{Fe}_{2} \mathrm{O}_{2} \mathrm{P}_{2} \mathrm{~S}_{4}: 633.8828$.

2,5-Diferrocenyl-1,6,3,4,2,5-dioxadithiadiphosphecane 2,5-disulfide (3). Yellow powder (0.430 g, 66\%). M.p. 145-147 ${ }^{\circ} \mathrm{C}$. Selected IR (KBr, cm $\left.{ }^{-1}\right)$ : 1459(m), 1410(m), 1176(s), 1103(m), 1078(m), 1025(m), 993(vs), 922(m), 821(s), 764(s), 664(s), 534(s), 488(vs). ${ }^{1} \mathrm{H}-\mathrm{NMR}\left(400.1 \mathrm{MHz}, \mathrm{CDCl}_{3}, \delta\right), 4.85-4.48(\mathrm{~m}, 8 \mathrm{H})$, $4.34(\mathrm{~s}, 10 \mathrm{H}), 3.89-3.77(\mathrm{~m}, 4 \mathrm{H}), 2.23-2.02(\mathrm{~m}, 4 \mathrm{H}) \mathrm{ppm} .{ }^{13} \mathrm{C}-\mathrm{NMR}\left(100.6 \mathrm{MHz}, \mathrm{CDCl}_{3}, \delta\right), 76.6$ $(\mathrm{d}, J(\mathrm{P}, \mathrm{C})=134.1 \mathrm{~Hz}), 72.7(\mathrm{~d}, J(\mathrm{P}, \mathrm{C})=10.2 \mathrm{~Hz}), 71.6(\mathrm{~d}, J(\mathrm{P}, \mathrm{C})=22.9 \mathrm{~Hz}), 70.3,66.4,27.4 \mathrm{ppm} .{ }^{31} \mathrm{P}-\mathrm{NMR}$ $\left(162.0 \mathrm{MHz}, \mathrm{CDCl}_{3}, \delta\right), 92.6 \mathrm{ppm}$. Accurate mass measurement $\left[\mathrm{EI}^{+}, \mathrm{m} / z\right]: 647.8982[\mathrm{M}]^{+}$, calculated mass for $\mathrm{C}_{24} \mathrm{H}_{26} \mathrm{Fe}_{2} \mathrm{O}_{2} \mathrm{P}_{2} \mathrm{~S}_{4}$ : 647.8985 .

7,8-Dimethyl-2,5-diferrocenyl-1,6,3,4,2,5-dioxadithiadiphosphocane 2,5-disulfide (4). Pale yellow solid (0.410 g, 63\%). M.p. $63-65^{\circ} \mathrm{C}$. Selected IR (KBr, $\left.\mathrm{cm}^{-1}\right)$ : 1412(m), 1383(m), 1185(s), 1026(vs), 976(m), 909(s), 823(s), 791(s), 731(s), 669(s), 536(s), 492(s), 474(s). ${ }^{1} \mathrm{H}-\mathrm{NMR}\left(400.1 \mathrm{MHz}, \mathrm{CDCl}_{3}, 8\right), 4.81-4.48(\mathrm{~m}, 8 \mathrm{H})$, $4.35(\mathrm{~s}, 10 \mathrm{H}), 3.89-3.77(\mathrm{~m}, 2 \mathrm{H}), 1.49(\mathrm{~d}, J(\mathrm{H}, \mathrm{H})=6.1 \mathrm{~Hz}, 6 \mathrm{H}) \mathrm{ppm} .{ }^{13} \mathrm{C}-\mathrm{NMR}\left(100.6 \mathrm{MHz}, \mathrm{CDCl}_{3}, \delta\right)$, $77.6(\mathrm{~d}, J(\mathrm{P}, \mathrm{C})=146.6 \mathrm{~Hz}), 72.4(\mathrm{~d}, J(\mathrm{P}, \mathrm{C})=11.9 \mathrm{~Hz}), 71.6(\mathrm{~d}, J(\mathrm{P}, \mathrm{C})=12.8 \mathrm{~Hz}), 70.4,70.3,19.5 \mathrm{ppm}$. ${ }^{31} \mathrm{P}-\mathrm{NMR}\left(162.0 \mathrm{MHz}, \mathrm{CDCl}_{3}, \delta\right), 90.1 \mathrm{ppm}$. Accurate mass measurement $\left[\mathrm{CI}^{+}, \mathrm{m} / z\right]: 645.9034[\mathrm{M}+$ $\mathrm{H}]^{+}$, calculated mass for $\mathrm{C}_{24} \mathrm{H}_{25} \mathrm{Fe}_{2} \mathrm{O}_{2} \mathrm{P}_{2} \mathrm{~S}_{4} \mathrm{H}$ : 645.9031 .

8-Ethyl-2,5-diferrocenyl-7-propyl-1,6,3,4,2,5-dioxadithiadiphosphonane 2,5-disulfide (6). Bright yellow solid $(0.510 \mathrm{~g}, 72 \%)$. Four diastereoisomers were found in ca. 2:1:1:1:2 intensity ratio in ${ }^{31} \mathrm{P}-\mathrm{NMR}$ spectra. Selected IR (KBr, cm $\left.{ }^{-1}\right)$ : 1459(m), 1411(m), 1386(m), 1365(m), 1184(s), 1107(m), 1024(vs), 972(s), 821(s), 677(vs), 536(s), 487(s). ${ }^{1} \mathrm{H}-\mathrm{NMR}\left(400.1 \mathrm{MHz}, \mathrm{CDCl}_{3}, \delta\right), 4.83-4.49(\mathrm{~m}, 32 \mathrm{H}, 4.38$ (s, 10H), $4.37(\mathrm{~s}, 10 \mathrm{H})$, $4.36(\mathrm{~s}, 10 \mathrm{H}), 4.35(\mathrm{~s}, 10 \mathrm{H}), 4.30-4.25(\mathrm{~m}, 12 \mathrm{H}), 2.85-2.76(\mathrm{~m}, 1 \mathrm{H}), 2.73-2.64(\mathrm{~m}, 1 \mathrm{H}), 2.07-1.04(\mathrm{~m}, 12 \mathrm{H}$ $\times 4) \mathrm{ppm} .{ }^{13} \mathrm{C}-\mathrm{NMR}\left(100.6 \mathrm{MHz}, \mathrm{CDCl}_{3}, \delta\right), 77.4(\mathrm{~d}, J(\mathrm{P}, \mathrm{C})=109 \mathrm{~Hz}), 77.3(\mathrm{~d}, J(\mathrm{P}, \mathrm{C})=108 \mathrm{~Hz}), 75.8(\mathrm{~d}$, $J(\mathrm{P}, \mathrm{C})=133 \mathrm{~Hz}), 74.4(\mathrm{~d}, J(\mathrm{P}, \mathrm{C})=133 \mathrm{~Hz}), 72.7(\mathrm{~d}, J(\mathrm{P}, \mathrm{C})=16.0 \mathrm{~Hz}), 72.5(\mathrm{~d}, J(\mathrm{P}, \mathrm{C})=14.4 \mathrm{~Hz}), 72.4(\mathrm{~d}$, $J(\mathrm{P}, \mathrm{C})=10.0 \mathrm{~Hz}), 72.3(\mathrm{~d}, J(\mathrm{P}, \mathrm{C})=13.5 \mathrm{~Hz}), 72.1(\mathrm{~d}, J(\mathrm{P}, \mathrm{C})=18.6 \mathrm{~Hz}), 72.0(\mathrm{~d}, J(\mathrm{P}, \mathrm{C})=19.0 \mathrm{~Hz}), 71.8(\mathrm{~d}$, $J(\mathrm{P}, \mathrm{C})=21.0 \mathrm{~Hz}), 71.4(\mathrm{~d}, J(\mathrm{P}, \mathrm{C})=22.9 \mathrm{~Hz}), 70.6,70.5,70.4,70.4,64.1(\mathrm{~d}, J(\mathrm{P}, \mathrm{C})=9.0 \mathrm{~Hz}), 61.3(\mathrm{~d}, J(\mathrm{P}, \mathrm{C})=$ 8.6 Hz), $42.1(\mathrm{t}, J(\mathrm{P}, \mathrm{C})=14.5 \mathrm{~Hz}), 41.0(\mathrm{t}, J(\mathrm{P}, \mathrm{C})=14.0 \mathrm{~Hz}), 34.3,34.1,19.7,18.7,17.4,15.4,14.4,14.0,12.4$, 11.5 ppm. ${ }^{31} \mathrm{P}-\mathrm{NMR}\left(162.0 \mathrm{MHz}, \mathrm{CDCl}_{3}, \delta\right), 94.0(\mathrm{~d}, J(\mathrm{P}, \mathrm{P})=4.3 \mathrm{~Hz}), 92.0(\mathrm{~d}, J(\mathrm{P}, \mathrm{P})=4.7 \mathrm{~Hz}), 90.7(\mathrm{~d}$, $J(\mathrm{P}, \mathrm{P})=4.7 \mathrm{~Hz}), 88.5(\mathrm{~d}, J(\mathrm{P}, \mathrm{P})=4.7 \mathrm{~Hz}) \mathrm{ppm}$. Accurate mass measurement $\left[\mathrm{EI}^{+}, m / z\right]: 703.9614[\mathrm{M}]^{+}$, calculated mass for $\mathrm{C}_{28} \mathrm{H}_{34} \mathrm{Fe}_{2} \mathrm{O}_{2} \mathrm{P}_{2} \mathrm{~S}_{4}$ : 703.9610.

3.2.2. General Procedure for the Reaction of FcLR with Aryl-diols (pyrocatechol, naphthalene-2,3-diol, $\left[1,1^{\prime}\right.$-binaphthalene $]-2,2^{\prime}$-diol) and $\mathrm{I}_{2}$

A mixture of aryl-diol $(1.0 \mathrm{mmol})$ and FcLR $(0.56 \mathrm{~g}, 1.0 \mathrm{mmol})$ in dry acetonitrile $(40 \mathrm{~mL})$ was stirred in the presence of triethylamine $(0.202 \mathrm{~g}, 2.0 \mathrm{mmol})$ at room temperature overnight. $\mathrm{I}_{2}$ solution $(0.254 \mathrm{~g}, 1.0 \mathrm{mmol})$ in acetonitrile $(15 \mathrm{~mL})$ was added dropwise during $2 \mathrm{~h}$ and the mixture was continued stirring for another $2 \mathrm{~h}$. Upon removal of the solvent, the residue was extracted with dichloromethane $(20 \mathrm{~mL} \times 3)$. After removal of the solvent, the crude product was purified by silica column (dichloromethane as eluent) to give the mono-phosphorus species 7, 9 and 11, and di-phosphorus species $\mathbf{8}, \mathbf{1 0}$ and $\mathbf{1 2}$.

2,5-Diferrocenylbenzo[g][1,6,3,4,2,5]dioxadithiadiphosphocine 2,5-disulfide (8). Yellow paste (0.330 g, 49\%). Selected IR (KBr, cm $\left.{ }^{-1}\right)$ : 1597(m), 1494(s), 1415(m), 1259(s), 1174(s), 1094(m), 1030(s), 913(s), 819(s), 755(s), 713(m), 664(s), 497(s). ${ }^{1} \mathrm{H}-\mathrm{NMR}\left(400.1 \mathrm{MHz}, \mathrm{CD}_{2} \mathrm{Cl}_{2}, 8\right), 7.15-6.85(\mathrm{~m}, 4 \mathrm{H}), 4.69-4.56(\mathrm{~m}, 8 \mathrm{H})$, $4.38(\mathrm{~s}, 10 \mathrm{H}) \mathrm{ppm} .{ }^{13} \mathrm{C}-\mathrm{NMR}\left(100.6 \mathrm{MHz}, \mathrm{CD}_{2} \mathrm{Cl}_{2}, \delta\right), 138.5,126.4,118.0,72.2(\mathrm{~d}, J(\mathrm{P}, \mathrm{C})=177.4 \mathrm{~Hz}), 72.1$ 
$(\mathrm{d}, J(\mathrm{P}, \mathrm{C})=14.0 \mathrm{~Hz}), 71.6(\mathrm{~d}, J(\mathrm{P}, \mathrm{C})=15.5 \mathrm{~Hz}), 70.5 \mathrm{ppm} .{ }^{31} \mathrm{P}-\mathrm{NMR}\left(162.0 \mathrm{MHz}, \mathrm{CD}_{2} \mathrm{Cl}_{2}, \delta\right), 95.5 \mathrm{ppm}$. Accurate mass measurement $\left[\mathrm{CI}^{+}, m / z\right]: 668.8751[\mathrm{M}+\mathrm{H}]^{+}$, calculated mass for $\mathrm{C}_{26} \mathrm{H}_{22} \mathrm{Fe}_{2} \mathrm{O}_{2} \mathrm{P}_{2} \mathrm{~S}_{4} \mathrm{H}$ : 668.8754 .

2-Ferrocenylnaphtho[2,3-d][1,3,2]dioxaphosphole 2-sulfide (9). Yellow paste (0.15 g, 29\%). Selected IR (KBr, $\left.\mathrm{cm}^{-1}\right)$ : 1509(m), 1471(s), 1260(s), 1189(s), 1151(m), 1100(s), 1029(s), 927(s), 889(s), 801(s), 744(s), 686(s), 497(s). ${ }^{1} \mathrm{H}-\mathrm{NMR}\left(400.1 \mathrm{MHz}, \mathrm{CD}_{2} \mathrm{Cl}_{2}, \delta\right), 7.84(\mathrm{~d}, J(\mathrm{P}, \mathrm{H})=3.3 \mathrm{~Hz}, 1 \mathrm{H}), 7.82$ $(\mathrm{d}, J(\mathrm{P}, \mathrm{H})=3.3 \mathrm{~Hz}, 1 \mathrm{H}), 7.50-7.47(\mathrm{~m}, 4 \mathrm{H}), 4.60-4.56(\mathrm{~m}, 4 \mathrm{H}), 4.47(\mathrm{~s}, 5 \mathrm{H}) \mathrm{ppm} .{ }^{13} \mathrm{C}-\mathrm{NMR}(100.6 \mathrm{MHz}$, $\left.\mathrm{CD}_{2} \mathrm{Cl}_{2}, \delta\right), 144.8,130.3,127.4,126.5,108.4,73.2(\mathrm{~d}, J(\mathrm{P}, \mathrm{C})=14.9 \mathrm{~Hz}), 72.5(\mathrm{~d}, J(\mathrm{P}, \mathrm{C})=17.8 \mathrm{~Hz})$, 71.1, $69.8(\mathrm{~d}, J(\mathrm{P}, \mathrm{C})=160.1 \mathrm{~Hz}) \mathrm{ppm} .{ }^{31} \mathrm{P}-\mathrm{NMR}\left(162.0 \mathrm{MHz}, \mathrm{CD}_{2} \mathrm{Cl}_{2}, \delta\right), 114.1 \mathrm{ppm}$. Accurate mass measurement $\left[\mathrm{EI}^{+}, m / z\right]: 405.9878[\mathrm{M}]^{+}$, calculated mass for $\mathrm{C}_{20} \mathrm{H}_{16} \mathrm{FeO}_{2} \mathrm{PS}: 405.9880$.

2,5-Diferrocenylnaphtho[2,3-g][1,6,3,4,2,5]dioxadithiadiphosphocine 2,5-disulfide (10). Yellow paste (0.259 g, 36\%). M.p. 202-204 ${ }^{\circ} \mathrm{C}$. Selected IR (KBr, cm $\left.{ }^{-1}\right)$ : 1513(s), 1471(s), 1410(m), 1366(m), 1265(s), 1189(m), 1115(m), 1103(s), 1031(s), 886(s), 800(s), 743(s), 685(s), 493(s), 455(m). ${ }^{1} \mathrm{H}-\mathrm{NMR}\left(400.1 \mathrm{MHz}, \mathrm{CD}_{2} \mathrm{Cl}_{2}\right.$,

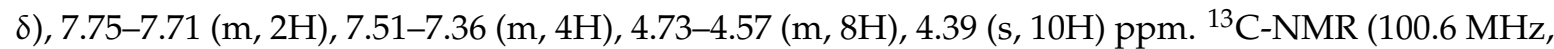
$\left.\mathrm{CD}_{2} \mathrm{Cl}_{2}, \delta\right), 146.9,132.2,127.1,126.0,112.7,74.2(\mathrm{~d}, J(\mathrm{P}, \mathrm{C})=104.9 \mathrm{~Hz}), 72.2(\mathrm{~d}, J(\mathrm{P}, \mathrm{C})=13.9 \mathrm{~Hz})$, $71.0(\mathrm{~d}, J(\mathrm{P}, \mathrm{C})=17.4 \mathrm{~Hz}), 70.6 \mathrm{ppm} .{ }^{31} \mathrm{P}-\mathrm{NMR}\left(162.0 \mathrm{MHz}, \mathrm{CD}_{2} \mathrm{Cl}_{2}, \delta\right), 95.6 \mathrm{ppm}$. Accurate mass measurement $\left[\mathrm{CI}^{+}, m / z\right]: 718.8908[\mathrm{M}+\mathrm{H}]^{+}$, calculated mass for $\mathrm{C}_{30} \mathrm{H}_{24} \mathrm{Fe}_{2} \mathrm{O}_{2} \mathrm{P}_{2} \mathrm{~S}_{4} \mathrm{H}$ : 718.8911.

4-Ferrocenyldinaphtho[2,1-d:1', 2'-f][1,3,2]dioxaphosphepine 4-sulfide (11). Pale yellow solid (0.22 g, 41\%). M.p. 170-172 ${ }^{\circ} \mathrm{C}$ (Dec.). Selected IR (KBr, cm $\left.{ }^{-1}\right)$ : 1586(m), 1502(m), 1467(m), 1409(m), 1538(m), 1209(s), 1184(s), 1071(m), 1026(s), 990(vs), 951(s), 832(s), 814(s), 708(s), 677(m), 650(m), 584(m), 481(s), 437(m). ${ }^{1} \mathrm{H}-\mathrm{NMR}\left(400.1 \mathrm{MHz}, \mathrm{CDCl}_{3}, \delta\right), 8.86(\mathrm{~d}, J(\mathrm{H}, \mathrm{H})=9.0 \mathrm{~Hz}, 2 \mathrm{H}), 8.27-7.08(\mathrm{~m}, 10 \mathrm{H}), 4.58-4.44(\mathrm{~m}, 4 \mathrm{H})$, 4.39 (s, 5H) ppm. ${ }^{13} \mathrm{C}-\mathrm{NMR}\left(100.6 \mathrm{MHz}, \mathrm{CDCl}_{3}, \delta\right), 134.0,131.3,130.4(\mathrm{~d}, J(\mathrm{P}, \mathrm{C})=21.4 \mathrm{~Hz}), 129.9,128.5$, $127.7,127.0(\mathrm{~d}, J(\mathrm{P}, \mathrm{C})=14.7 \mathrm{~Hz}), 126.5(\mathrm{~d}, J(\mathrm{P}, \mathrm{C})=5.8 \mathrm{~Hz}), 126.0,119.5,73.9(\mathrm{~d}, J(\mathrm{P}, \mathrm{C})=107.9 \mathrm{~Hz}), 72.5$ $(\mathrm{d}, J(\mathrm{P}, \mathrm{C})=15.7 \mathrm{~Hz}), 71.9(\mathrm{~d}, J(\mathrm{P}, \mathrm{C})=20.0 \mathrm{~Hz}), 70.9 \mathrm{ppm} .{ }^{31} \mathrm{P}-\mathrm{NMR}\left(162.0 \mathrm{MHz}, \mathrm{CDCl}_{3}, \delta\right), 107.8 \mathrm{ppm}$. Accurate mass measurement $\left[\mathrm{EI}^{+}, m / z\right]: 532.0341[\mathrm{M}]^{+}$, calculated mass for $\mathrm{C}_{30} \mathrm{H}_{21} \mathrm{FeO}_{2} \mathrm{PS}: 532.0344$.

8,11-Diferrocenyldinaphtho[2,1-g:1',2'-i][1,6,3,4,2,5]dioxadithiadiphosphecine 8,11-disulfide (12). Pale yellow solid $\left(0.35\right.$ g, 42\%). M.p. $238-240{ }^{\circ} \mathrm{C}$. Selected IR (KBr, cm $\left.{ }^{-1}\right)$ : 1587(m), 1543(m), 1460(m), 1409(m), 1539(m), 1321(m), 1224(s), 1184(s), 1070(s), 1024(s), 988(s), 952(s), 833(s), 753(s), 728(s), 706(m), 680(m), 650(m), 587(m), 484(s). ${ }^{1} \mathrm{H}-\mathrm{NMR}\left(400.1 \mathrm{MHz}, \mathrm{CDCl}_{3}, \delta\right), 8.89(\mathrm{~d}, \mathrm{~J}(\mathrm{H}, \mathrm{H})=9.1 \mathrm{~Hz}, 2 \mathrm{H}), 8.22-7.06(\mathrm{~m}$, 10H), 4.90-4.28 (m, 8H), 4.38 (s, 10H) ppm. ${ }^{13} \mathrm{C}-\mathrm{NMR}\left(100.6 \mathrm{MHz}, \mathrm{CDCl}_{3}, \delta\right), 134.0,131.3,130.4,129.9$, 128.6, 127.7, $127.2(\mathrm{~d}, J(\mathrm{P}, \mathrm{C})=14.8 \mathrm{~Hz}), 126.5,125.6,119.5,74.0(\mathrm{~d}, J(\mathrm{P}, \mathrm{C})=113.1 \mathrm{~Hz}), 72.3(\mathrm{~d}, J(\mathrm{P}, \mathrm{C})=$ $15.8 \mathrm{~Hz}), 71.8(\mathrm{~d}, J(\mathrm{P}, \mathrm{C})=23.8 \mathrm{~Hz}), 70.9 \mathrm{ppm} .{ }^{31} \mathrm{P}-\mathrm{NMR}\left(162.0 \mathrm{MHz}, \mathrm{CDCl}_{3}, \delta\right), 92.0 \mathrm{ppm}$. Accurate mass measurement $\left[\mathrm{EI}^{+}, m / z\right]: 843.9308[\mathrm{M}]^{+}$, calculated mass for $\mathrm{C}_{40} \mathrm{H}_{30} \mathrm{Fe}_{2} \mathrm{O}_{2} \mathrm{P}_{2} \mathrm{~S}_{4}: 843.9303$.

\subsubsection{Synthesis of Compound 13}

A mixture of but-2-yne-1,4-diol $(0.086 \mathrm{~g}, 1.0 \mathrm{mmol})$ and FcLR $(0.560 \mathrm{~g}, 1.0 \mathrm{mmol})$ in dry acetonitrile $(40 \mathrm{~mL})$ was stirred in the presence of triethylamine $(0.404 \mathrm{~g}, 4.0 \mathrm{mmol})$ at room temperature overnight. $\mathrm{I}_{2}$ solution $(0.254 \mathrm{~g}, 1.0 \mathrm{mmol})$ in acetonitrile $(15 \mathrm{~mL})$ was added dropwise over $2 \mathrm{~h}$ and the mixture was continued stirring for another $2 \mathrm{~h}$. After removal of the solvent, the residue was extracted with dichloromethane $(20 \mathrm{~mL} \times 3)$. The crude product was purified by silica column (1:1 hexane/dichloromethane as eluent) to give the title compound $\mathbf{1 3}$ as dark yellow solid $(0.480 \mathrm{~g}, 77 \%)$.

\subsubsection{General Procedure for the Reaction of FcLR with Alkenyl-diols and $\mathrm{SOCl}_{2}$}

A mixture of alkenyl-diol $(1.0 \mathrm{mmol})$ and FcLR $(0.56 \mathrm{~g}, 1.0 \mathrm{mmol})$ in dry THF $(40 \mathrm{~mL})$ was stirred in the presence of triethylamine $(0.202 \mathrm{~g}, 2.0 \mathrm{mmol})$ at room temperature for $2 \mathrm{~h}$. Then the mixture was cooled down to $0{ }^{\circ} \mathrm{C}$ and $\mathrm{SOCl}_{2}$ solution $(0.120 \mathrm{~g}, 1.0 \mathrm{mmol})$ in THF $(15 \mathrm{~mL})$ was added dropwise over $1 \mathrm{~h}$ and the mixture was continued stirring for another $2 \mathrm{~h}$. After removal of the solvent, the residue 
was extracted with dichloromethane $(3 \times 20 \mathrm{~mL})$. The crude product was purified by silica column (dichloromethane as eluent) to give the di-phosphorus species $1(35 \%), 2(31 \%), 3(12 \%)$ and $6(25 \%)$.

\section{Conclusions}

In summary, we have successfully developed an efficient approach for the synthesis of a series of novel nine- and ten-membered organophosphorus-sulfur heterocycles with P-S-S-P linkage via a one-pot cyclisation reacton of four-membered ring thionation reagent, 2,4-diferrocenyl-1,3,2,4-diathiadiphosphetane 2,4-disulfide (FCLR), alkenyl-diols or aryl-diols and iodine or $\mathrm{SOCl}_{2}$ in the presence of triethylamine. In the case of aryl-diol, an additional five-membered monophosphorus species was obtained apart from the expected thw di-phosphorus species. Seven representative X-ray structures confirm the formation of these organophosphorus-sulfur heterocycles. The reported results enrich the library of organophosphorus-sulfur heterocycles and provide an efficient and envirmentally benign approach to the preparation of the unusual up to ten-membered phosphorus-sulfur heterocycles incorporating an P-S-S-P scaffold.

Supplementary Materials: Supplementary Materials are available online.

Acknowledgments: We are grateful to the University of St Andrews for financial support and the EPSRC National Mass Spectrometry Service Centre (Swansea) for mass spectral measurements.

Author Contributions: G.H. and J.D.W. conceived and designed; G.H. and K.D. performed the experiments; D.B.C., J.D. and A.M.Z.S. finished the X-ray structure measurement; J.D.W. provided critical intellectual input in this study; all authors participated in the preparation of the manuscript.

Conflicts of Interest: The authors declare no conflict of interest.

\section{References}

1. Bao, M.; Shimizu, M. N-Trifluoroacetyl arenesulfenamides, effective precursors for synthesis of unsymmetrical disulfides and sulfenamides. Tetrahedron 2003, 59, 9655-9659. [CrossRef]

2. Cremlyn, R.; An, J. Introduction to Organosulfur Chemistry; Wiley \& Sons: New York, NY, USA, 1996.

3. Fletcher, J.M.; Hughes, R.A. A novel approach to the regioselective synthesis of a disulfide-linked heterodimeric bicyclic peptide mimetic of brain-derived neurotrophic factor. Tetrahedron Lett. 2004, 45, 6999-7001. [CrossRef]

4. Vruhula, V.M.; MacMaster, J.F.; Li, Z.; Kerr, D.E.; Senter, P.D. Reductively activated disulfide prodrugs of paclitaxel. Bioorg. Med. Chem. Lett. 2002, 12, 3591-3594. [CrossRef]

5. Roy, B.; Chambert, S.; Leoivre, M.; Aubertin, A.M.; Balzarini, J.; Decout, J.L. Deoxyribonucleoside-2'- or 3'-mixed disulfides: prodrugs to target ribonucleotide reductase and /or to inhibit HIV reverse transcription. J. Med. Chem. 2003, 46, 2565-2568. [CrossRef] [PubMed]

6. Mu, Y.; Nodwell, M.; Pace, J.L.; Shaw, J.P.; Judice, J.K. Vancomycin disulfide derivatives as antibacterial agents. Bioorg. Med. Chem. Lett. 2004, 14, 735-738. [CrossRef] [PubMed]

7. Ulman, A. Formation and structure of self-assembled monolayers. Chem. Rev. 1996, 96, 1533-1554. [CrossRef] [PubMed]

8. Ulman, A. Thin Films: Self-Assembled Monolayers of Thiols; Academic Press: Boston, MA, USA, 1998.

9. Porter, L.A., Jr.; Ji, D.; Westcott, S.L.; Graupe, M.; Czernuszewicz, R.S.; Halas, N.J.; Lee, T.R. Gold and silver nanoparticles functionalized by the adsorption of dialkyl disulfides. Langmuir 1998, 14, 7378-7386. [CrossRef]

10. Shon, Y.S.; Mazzitelli, C.; Murray, R.W. Unsymmetrical disulfides and thiol mixtures produce different mixed monolayer-protected gold clusters. Langmuir 2001, 17, 7735-7741. [CrossRef]

11. Sato, R.; Ohyama, T.; Ogawa, S. Efficient synthesis and biological properties of new benzopentathiepins. Heterocycles 1995, 41, 893-896. [CrossRef]

12. Toste, F.D.; Still, I.W.J. A new route to the synthesis of the naturally occurring benzopentathiepin varacin. J. Am. Chem. Soc. 1995, 117, 7261-7262. [CrossRef]

13. Searle, P.A.; Molinski, T.F. Five new alkaloids from the tropical ascidian, Lissoclinum sp. lissoclinotoxin A is chiral. J. Org. Chem. 1994, 59, 6600-6605. [CrossRef] 
14. Davidson, B.S.; Ford, P.W.; Wahlman, M. Chirality in unsymmetrically substituted benzopentathiepins: The results of a high barrier to ring inversion. Tetrahedron Lett. 1994, 35, 7185-7188. [CrossRef]

15. Behar, V.; Danishefsky, S.J. Total synthesis of the novel benzopentathiepin varacinium trifluoroacetate: The viability of "varacin-free base". J. Am. Chem. Soc. 1993, 115, 7017-7018. [CrossRef]

16. Ford, P.W.; Davidson, B.S. Synthesis of varacin, a cytotoxic naturally occurring benzopentathiepin isolated from a marine ascidian. J. Org. Chem. 1993, 58, 4522-4523. [CrossRef]

17. Davidson, B.S.; Molinski, T.F.; Barrows, L.R.; Ireland, C.M. Varacin: A novel benzopentathiepin from lissoclinium vareau that is cytotoxic toward a human colon tumour. J. Am. Chem. Soc. 1991, 113, 4709-4710. [CrossRef]

18. Janosik, T.; Bergman, J.; Stensland, B.; Stalhandske, C. Thionation of bisindole derivatives with P4S10 or elemental sulfur. J. Chem. Soc. Perkin Trans. I 2002, 330-334. [CrossRef]

19. Macho, S.; Rees, C.W.; Rodriguez, T.; Torroba, T. A novel oxime to pentathiepin cascade reaction. Chem. Commun. 2001, 403-404. [CrossRef]

20. Bergman, J.; Stalhandske, C. Transformation of isatin with P4S10 to pentathiepino[6,7-b]indole in one step. Tetrahedron Lett. 1994, 35, 5279-5282. [CrossRef]

21. Grishina, O.N.; Kosova, L.M.; Lipatova, I.P.; Shagidullin, R.R. Sulfides of alkylthionophosphines. IX. Synthesis of pentaerythritol-O,O,O,O-tetrakis(alkyldithioophosphonates) and their derivatives. Zh. Obsch. KHim 1970, 40, 66-69.

22. Przychodzen, W. New products of reaction of Lawesson's ragent with diols. Phosphorus Sulfur Silicon Relat. Elem. 2004, 179, 1621-1633. [CrossRef]

23. Pillay, M.N.; van der Wailt, H.; Staples, R.J.; Van Zyl, W.E. C/O/P/S cyclic derived from oxidative intramolecular disulfide (-S-S-) coupling of ferrocenyl dithiophopshonates. J. Organomet. Chem. 2015, 794, 33-39. [CrossRef]

24. Hua, G.; Slawin, A.M.Z.; Randall, R.A.M.; Cordes, D.B.; Crawford, L.; Bühl, M.; Woollins, J.D. An efficient route for the synthesis of phosphorus-selenium macro-heterocycles. Chem. Commun. 2013, 49, 2619-2621. [CrossRef] [PubMed]

25. Hua, G.; Du, J.; Cordes, D.B.; Slawin, A.M.Z.; Woollins, J.D. One-pot three-component condensation synthesis and structural features of organophosphorus-sulfur macrocycles. J. Org. Chem. 2016, 81, 4210-4225. [CrossRef] [PubMed]

26. Hua, G.; Du, J.; Slawin, A.M.Z.; Woollins, J.D. One-pot approach to organo-phosphorus-chalcogen macrocycles incorporating double OP(S)SCn or OP(Se)SeCn scaffolds: A synthetic and structural study. Chem. Eur. J. 2016, 22, 7782-7791. [CrossRef] [PubMed]

27. Foreman, M.R., St.; Slawin, A.M.Z.; Woollins, J.D. 2,4-Diferrocenyl-1,3-dithiadiphosphetane 2,4-disulfide; structure and reactions with catechols and $\left[\mathrm{PtCl}_{2}\left(\mathrm{PR}_{3}\right)_{2}\right](\mathrm{R}=\mathrm{Et}$ or Bu). J. Chem. Soc. Dalton Trans. 1996, 3653-3657. [CrossRef]

28. Gray, I.P.; Slawin, A.M.Z.; Woollins, J.D. Synthesis and characterization of disulfides and esters derived from their sodium organodithiophosphonate salts. New J. Chem. 2004, 28, 1383-1389. [CrossRef]

29. Grossmann, G.; Komber, H. NMR investigation on diastereomeric mixtures of bis(dialkoxythiophosphoryl) sulfides and polysulfides containing sec-butoxy groups. Assignment of phosphorus-31, carbon-13 and proton NMR signals in a mixture of seven diastereomers using shift-correlated 2D NMR spectra. Phosphorus Sulfur Silicon Relat. Elem. 1991, 61, 269-281.

30. Ogawa, S.; Ohmiya, T.; Kikuchi, T.; Kawaguchi, A.; Saito, S.; Sai, A.; Kawai, Y.; Niizuma, S.; Nakajo, S.; Kimura, T.; et al. Synthesis, structure, and one-electron redox reactions of 4,7-disubstituted benzotrichalcogenoles containing sulfur and /or selenium atoms. J. Organoment. Chem. 2000, 611, 136-145. [CrossRef]

31. Jesberger, M.; Davis, T.P.; Bamer, L. Applications of Lawesson's reagent in organic and organometallic syntheses. Synthesis 2003, 1929-1958. [CrossRef]

32. Fuller, A.L.; Scott-Hayward, L.A.S.; Li, Y.; Bühl, M.; Slawin, A.M.Z.; Woollins, J.D. Automated Chemical Crystallography. J. Am. Chem. Soc. 2010, 132, 5799-5802. [CrossRef] [PubMed]

33. CrystalClear-SM Expert v3.1b27; Rigaku Corporation: The Woodlands, TX, USA; Tokyo, Japan, 2013.

34. CrystalClear-SM Expert v2.1; Rigaku Corporation: The Woodlands, TX, USA; Tokyo, Japan, 2015.

35. Palatinus, L.; Chapuis, G. SUPERFLIP-A computer program for the solution of crystal structures by charge flipping in arbitrary dimensions. J. Appl. Cryst. 2007, 40, 786-790. [CrossRef] 
36. Burla, M.C.; Caliandro, R.; Camalli, M.; Carrozzini, B.; Cascarano, G.L.; De Caro, L.; Giacovazzo, C.; Polidori, G.; Spagna, R. SIR2004: An improved tool for crystal structure determination and refinement. J. Appl. Cryst. 2005, 38, 381-388. [CrossRef]

37. Burla, M.C.; Caliandro, R.; Camalli, M.; Carrozzini, B.; Cascarano, G.L.; Giacovazzo, C.; Mallamo, M.; Mazzone, A.; Polidori, G.; Spagna, R. SIR2011: A new package for crystal structure determination and refinement. J. Appl. Cryst. 2012, 45, 357-361. [CrossRef]

38. Sheldrick, G.M. Crystal structure refinement with SHELXL. Acta Crystallogr. Sect. C 2015, 71, 3-8.

39. CrystalStructure v4.2; Rigaku Corporation: The Woodlands, TX, USA; Tokyo, Japan, 2015.

Sample Availability: Samples of all compounds are not available from the authors.

(C) 2017 by the authors. Licensee MDPI, Basel, Switzerland. This article is an open access article distributed under the terms and conditions of the Creative Commons Attribution (CC BY) license (http://creativecommons.org/licenses/by/4.0/). 